\title{
PERTANYAAN KOGNITIF SISWA DALAM PEMBELAJARAN BAHASA INDONESIA DENGAN PENDEKATAN KONTEKSTUAL DI SMP KARTIKA AMBON
}

\author{
Carolina Sasabone \\ Universitas Pattimura \\ E-mail: carolinasasabone21@gmail.com
}

\begin{abstract}
Abstrak: Pertanyaan dalam kegiatan berbahasa atau berinteraksi sangat penting karena kegiatan berbahasa melibatkan pembicara dan pendengar dalam aktifitas tersebut. Dalam kegiatan sosial pertanyaan merupakan salah satu unsur pembentuk interaksi, sedangkan dalam proses belajar di kelas pertanyaan merupakan unsur pembentuk terjadinya interaksi kelas. Dalam pembelajaran bahasa yang menggunakan pendekatan kontekstual (PK), kegiatan bertanya atau pertanyaan merupakan cara atau strategi yang sangat penting yang dilakukan dalam pembelajaran kontekstual. Bagi guru, kegiatan bertanya merupakan cara yang digunakan untuk membimbing, dan memberikan motivasi, serta untuk menilai kemampuan berpikir siswa. Sedangkan tujuan bertanya bagi siswa, merupakan kegiatan penting karena dengan bertanya siswa dapat mengetahui apa yang seharusnya dilakukan dalam melaksanakan pempelajaran yang berbasis inquiri, yaitu siswa mencari informasi, mengkonfirmasikan apa yang sudah diketahui, dan memfokuskan perhatian pada aspek yang belum diketahuinya. Bentuk-bentuk pertanyaan yang digunakan siswa yaitu: (1) menggunakan kata-kata Tanya, (2) menggunakan intonasi Tanya, dan (3) menggunakan partikel Tanya. Fungsi dari pertanyaan-pertanyaan yang dikemukakan siswa dalam proses pembelajaran mempunyai berbagai fungsi sesuai dengan konteks percakapan atau konteks pembelajaran dengan materi yang berbedabeda. Fungsi pertanyaan yaitu untuk memperoleh penjelasan atau jawaban sebagai berikut : (1) klarifikasi, (2) konfirmasi, dan (3) retorika. Pertanyaan berdasarkan tingkat kognisi siswa, ternyata bahwa siswa SMP Kelas VIII sebagian besar masih berupa pertanyaan berada pada tingkat rendah yaitu $\mathrm{C} 1$ dan $\mathrm{C} 2$ atau pada tingkat mengingat dan memahami, yaitu masih berada pada tingkat berpikir rendah.
\end{abstract}

Kata Kunci: pertanyaan kognitif, pembelajaran bahasa Indonesia, pendekatan kontekstual 


\title{
COGNITIVE QUESTION OF STUDENT LEARNING INDONESIAN LANGUAGE WITH CONTEXTUAL APPROACH AT SMP KARTIKA AMBON
}

\author{
Carolina Sasabone \\ Pattimura University \\ E-mail: carolinasasabone21@gmail.com
}

\begin{abstract}
Questions in language or interacting activities have a very important role and occupy a central position. In social activities questions are one of the forming elements of interaction, whereas in the learning process in class questions are the forming elements of classroom interactions. In language learning that uses a contextual approach (PK), questions are the main strategy in contextual learning. For teachers, the questioning activity is seen as a teacher's effort to encourage, guide, and assess students' thinking abilities. As for students, the questioning activity is an important part of implementing inquiry-based learning, which is digging information, confirming what is already known, and directing attention to aspects that are not yet known. The forms of questions used by students are, by (1) using question words, (2) using question intonation, and (3) using question particles. The function of the questions posed by students in the learning process has various functions according to the context of the conversation or learning context with different material. The function of the question is: to obtain an explanation or answer as (1) clarification, (2) confirmation, and (3) rhetoric. Questions based on students' level of cognition, it turns out that most of the VIII Middle School students are still in the form of questions at the low level namely $\mathrm{C} 1$ and $\mathrm{C} 2$ or at the level of remembering and understanding, which is still at the low level of thinking.
\end{abstract}

Keywords: Cognitive questions, Indonesian language learning, contextual approach 


\section{A. PENDAHULUAN}

Era globalisasi yang terjadi sekarang ini telah menimbulkan persaingan yang sangat tajam dalam berbagai bidang. Bidang pendidikan merupakan salah satu bidang yang sangat diperhatikan dan menjadi sorotan. Oleh sebab itu, salah satu upaya yang sangat urgen untuk mengantisipasi globalisasi adalah dengan meningkatkan daya saing nasional melalui pendidikan (Syafi'ie, 2001). Peningkatan dalam bidang pendidikan ini dapat dilakukan melalui peningkatan pengetahuan dan keanekaragaman keterampilan agar siswa mampu memberdayakan dirinya untuk menemukan, menafsirkan, menggunakan informasi, serta melahirkan gagasan untuk menentukan sikap dan dalam mengambil keputusan. Dengan demikian, maka perlu adanya suatu pembaharuan dalam sistem pembelajaran kita yang dapat mengakomodasi harapan masyarakat dan pemerintah.

Khusus dalam bidang pendidikan bahasa Indonesia, penyempurnaan kurikulum itu disertai pula dengan penyempurnaan penggunaan pendekatan pengajaran bahasa. Penerapan penggunaan salah satu pendekatan adalah pendekatan kontekstual. Penggunaan pendekatan ini diharapkan dapat mengubah orientasi proses belajar-mengajar dari belajar bahasa secara umum, menjadi belajar bahasa dan memahaminya secara kontekstual.

Pertanyaan dalam kegiatan berbahasa atau berinteraksi memiliki peran dan tujuan yaitu untuk mengetahui atau mengklarifikasi sesuatu. Dalam kegiatan sosial pertanyaan merupakan salah satu unsur pembentuk interaksi, sedangkan dalam proses belajar di kelas pertanyaan merupakan unsur pembentuk terjadinya interaksi kelas. Dalam pembelajaran bahasa yang menggunakan pendekatan kontekstual (PK), pertanyaan dianggap sebagai suatu cara atau strategi yang sangat penting dalam pembelajaran kontekstual. Bagi guru, kegiatan bertanya merupakan cara yang digunakan untuk membimbing, dan memberikan motivasi, serta untuk menilai kemampuan berpikir siswa. Sedangkan tujuan bertanya bagi siswa merupakan kegiatan penting karena dengan bertanya siswa dapat mengetahui apa yang seharusnya dilakukan dalam melaksanakan pempelajaran yang berbasis inquiri, yaitu siswa mencari informasi, mengkonfirmasikan apa yang sudah diketahui, dan memfokuskan perhatian pada aspek yang belum diketahuinya. .

Dasar pemikiran untuk menggunakan pendekatan kontekstual adalah bahwa proses belajar-mengajar yang terjadi di kelas-kelas selama ini, adalah masih berfokus pada pencapaian penguasaan materi. Target atau fokus pencakaian materi ini hanya mampu dalam hal kompetensi mengingat jangka pendek, tetapi tidak mampu untuk membekali siswa untuk memecahkan persoalan ke depan atau persoalan jangka panjang (Nurhadi, 2002). Sejalan dengan itu, penggunaan pendekatan kontekstual akan membentuk pola belajar siswa sebagai berikut : (1) Memotivasi siswa agar terlibat secara aktif dalam proses pembelajaran, (2) Belajar bersama atau melalui kerja kelompok dan diskusi, siswa mengetahui lebih banyak baik pengetahuan maupun keterampilan karena bisa saling mengoreksi dan saling memberi input yang bermanfaat, (3) Siswa dapat mengaitkan pembelajaran dengan kehidupan nyata sehari-hari dan atau masalah yang disimulasikan, 
(4) perilaku siswa bisa berubah atas kesadaran diri sendiri tanpa ada paksaan pihak lain, (5) keterampilan dikembanmgkan apabila siswa memiliki pemahaman, (6) siswa dapat bertanggung jawab untuk mengembangkan pembelajaran yang mereka pelajari atau tekuni,

(7) siswa dapat menggunakan bahasa dengan pendekatan komunikatif, yaitu bagaimana menggunakan bahasa dalam konteks yang nyata, dan (8) siswa dituntut dapat berpikir kritis, terlihat aktif dalam proses pembelajaran yang efektif, dan ikut bertanggung jawab atas terjadinya proses pembelajaran yang efektif, serta dapat membawa skemata masingmasing ke dalam proses pembelajaran,( Nurhadi, 2002; Suparno, 2003).

Untuk mewujudkan harapan itu, dalam interaksi pembelajaran bahasa, pembinaan kemampuan dan keterampilan berbahasa khususnya keterampilan bertanya, menjawab pertanyaan, mengemukakan pendapat, berargumen, perlu mendapat perhatian serius. Dalam interaksi sosial, pertanyaan merupakan salah satu unsur pembentuk interaksi, sedangkan dalam proses pembelajaran dikelas pertanyaan merupakan unsur pembentuk interaksi kelas. Pertanyaan merupakan hal yang sangat mempengaruhi keberhasilan dalam melatih siswa berkomunikasi secara kontekstual.

Contoh :

Pertanyaan siswa : menurut kamu apa keluarga yang harmonis dan sehat itu ?

Konteks : pertanyaan ini disampaikan oleh siswa dalam kegiatan diskusi kelompok.

Pertanyaan tersebut menggunakan bentuk pertanyaan yang menggunakan kata tanya apa. Berdasarkan tingkat kognisi, pertanyaan tersebut termasuk kategori kognisi Sintesis (C5). Berdasarkan fungsi, pertanyaan tersebut meminta informasi atau penjelasan.

Berdasarkan paparan di atas, hal-hal yang mendorong sehingga penelitian ini dilakukan yaitu, (1) kemampuan siswa SMP untuk bertanya dalam pembelajaran masih sangat rendah, salah satu upaya untuk meningkatkan kemampuan tersebut adalah dengan meningkatkan efektivitas pembelajaran dengan menggunakan pertanyaan, (2) pertanyaan memiliki peranan yang sangat penting dalam pembelajaran yang menggunakan pendekatan kontekstual karena dapat menumbuhkan keterampilan berbahasa, keterampilan berpikir dan mengaktifkan siswa belajar.

\section{B. METODE PENELITIAN}

Penelitian yang dilakukan ini, merupakan jenis penelitian deskriptif dengan pendekatan kualitatif dengan pertimbangan bahwa (1) penelitian dilakukan dalam latar alamiah, (2) penelitian bersifat deskriptif, (3) peneliti berperan sebagai instrument utama, (4) peneliti menganalisis data secara indukti, (5) tuturan sebagai data utama penelitian (Bogdan dan Biklen, 1982: 27-36). Dengan menggunakan pendekatan ini, maka data penelitian yang diperoleh dideskripsikan berdasarkan, bentuk dan fungsi pertanyaan kognitif siswa dalam interaksi pembelajaran. Data penelitian ini berupa tuturan. Tuturan yang dimaksud yaitu pertanyaan-pertanyaan siswa dalam kegiatan pembelajaran di kelas. Baik pertanyaan siswa yang ditujukan kepada siswa maupun pertanyaan ditujukan kepada 
guru. Data tuturan ini diperoleh melalui rekaman, observasi dan catatan lapangan. Siswa sebagai sumber data yang menuturkan atau menggunakan pertanyaan kognitif dalam interaksi pembelajaran di kelas. Siswa sebagai sumber data yaitu siswa SMP kartika Ambon, kelas VIII.

Pengumpulan data dilakukan dengan teknik observasi, perekaman dan wawancawa tidak terstruktur, artinya tidak menggunakan pedoman wawancara secara khusus. Instrumen yang digunakan yaitu disesuaikan dengan teknik pengambilan data, seperti buku catatan untuk mencatat hal-hal yang tidak bisa diperoleh dengan rekaman, alat rekam dalam hal ini menggunakan handphone.

Penelitian ini menggunakan teknik analisis data model interaktif yang diadaptasi dari model yang dikembangkan oleh Miles dan Huberman (1992:21-23). Model interaktif itu mengemukakan tiga tahap kegiatan untuk melakukan analisis data yakni (1) reduksi data, (2) penyajian data, dan (3) penyimpulan data atau verifikasi.

\section{PEMBAHASAN}

\section{Bentuk-bentuk Pertanyaan}

Dalam pembelajaran, aktivitas yang tak kalah penting dari materi itu sendiri adalah kegiatan tanya jawab. Pertanyaan dari guru kepada siswa merupakan hal terpenting karena bertanya berarti guru ingin mengetahui kemampuan dan pemahaman siswa mengenai materi yang diberikan. Siswa bertanya merupakan hal yang juga diharapkan guru agar interaksi belajar mengajar berlangsung rileks dan kondusif.

Siswa bertanya berarti ia menyampaikan gagasannya berupa pertanyaan yang bertujuan untuk meminta respon atau tanggapan dari guru atau seseorang tentang pertanyaan yang diajukan. Tanggapan yang diinginkan bisa berupa penjelasan yang panjang maupun hanya berbentuk konfirmasi. Semua respon yang diterima tergantung dari pertanyaannya dan kondisi saat melakukan percakapan.

Berdasarkan beberapa pendapat, pembentukan pertanyaan dapat dilakukan dengan beberapa cara. Dari hasil penelitian, ditemukan bahwa pertanyaan yang diajukan siswa dalam proses interaksi pembelajaran di kelas, khususnya mata pelajaran Bahasa Indonesia terdapat tiga bentuk atau tiga cara, yaitu (a) dengan menggunakan kata-kata Tanya, (b) bertanya dengan menggunakan intonasi Tanya, dan (c) bertanya menggunakan partikel Tanya.

a) Penggunaan kata Tanya merupakan ciri penanda sebuah pertanyaan. Kata-kata Tanya seperti: mengapa, siapa, di mana, kapan, bagaimana, merupakan kata-kata Tanya yang digunakan siswa untuk bertanya.

Data (01) Bagaimana seseorang bisa membaca puisi jika ia tidak pernah menulis puisi? Pertanyaan tersebut diajukan siswa kepada guru, pada saat guru menyampaikan materi tentang membaca puisi. Ini berarti siswa menggunakan penanda kata Tanya 
bagaimana. Siswa ingin mendapatkan jawaban atau informasi tentang apa yang tidak diketahuinya.

Data (02) Mengapa disebut puisi lama dan puisi baru? Pertanyaan siswa ini menggunakan penanda kata Tanya mengapa. Siswa menggunakan penanda Tanya mengapa karena ingin mendapatkan jawaban yang panjang dan membutuhkan penjelasan yang jelas agar siswa lebih memahami tentang puisi lama dan puisi baru.

Data (03) Apa sebab bahasa persuasi itu dikatakan bahasa ajakan? Pertanyaan ini diajukan siswa kepada temannya dalam diskusi kelompok. Penanda apa sebagai pertanyaan menandakan bahwa siswa ingin mendapatkan informasi tentang sebab-sebab bahasa persuasi disebut bahasa ajakan, karena dalam diskusi kelompok tidak dijelaskan secara rinci mengenai hal tersebut. Hal inilah yang membuat siswa bertanya kepada temannya dari kelompok yang sedang membahas masalah tersebut.

Data (04) Siapa tokoh utama dalam cerita fiksi yang baru saja dibaca? Penanda pertanyaan apa dimaksudkan untuk menanyakan orang atau tokoh yang terdapat dalam cerita fiksi yang baru saja dibaca oleh teman dari kelompok lain. Ini terjadi dalam situasi diskusi kelas.

Data (5) Kapan sebuah karya sastra atau puisi dikatakan baik ibu? Pertanyaan siswa kepada guru yang mengajar materi puisi. Guru diminta memberi penjelasan tentang sebuah karya sastra atau puisi. Siswa belum mengerti bahwa karya sastra dikatakan baik atau tidak baik itu kapan, dan guru perlu menjelaskannya agar siswa lebih mengerti tentang karya sastra tersebut. Kapan disini sesuai konteks, berarti bukan berkaitan dengan tahun atau tanggal, tetapi lebih membutuhkan penjelasan panjang mengenai hal tersebut.

Pertanyaan-pertanyaan yang disampaikan siswa dalam proses pembelajaran, khususnya untuk bahasa Indonesia, menunjukkan bahwa situasi pembelajaran berjalan dengan baik, dan kondusif. Siswa aktif bertanya baik kepada guru maupun bertanya kepada teman dalam situasi diskusi kelompok. Pertanyaan-pertanyaan yang diajukan siswa dalam proses pembelajaran ini sangat bervariasi. Jadi berbagai bentuk pertanyaan dengan katakata Tanya yang menjadi penanda dalam mengajukan pertanyaan.

b) Pertanyaan dengan menggunakan intonasi Tanya.

Pertanyaan dengan penanda intonasi ada dua, yaitu intonasi naik dan intonasi turun. Kalimat tanya berintonasi naik digunakan untuk pertanyaan yang membutuhkan jawaban 'ya' atau 'tidak'. Sementara itu, kalimat tanya berintonasi turun digunakan untuk menanyakan sesuatu yang harus dijawab secara jelas.

Data (6) apakah di Indonesia terdapat musim dingin? Contoh data ini merupakan pertanyaan dengan penanda intonasi Tanya naik. Hal ini berarti penanya hanya membutuhkan jawaban ya atau tidak. Penanya tidak membutuhkan penjelasan. 
Data (7) teman yang tidak masuk hari ini, apakah ada berita? Penanda pertanyaan dengan intonasi naik menunjukkan bahwa, penanya hanya membutuhkan jawaban ya atau tidak. Bandingkan dengan data berikut ini.

Data (8) bagaimana kita menyimpulkan isi teks persuasif? Pada contoh data ini, penanya menggunakan Penanda intonasi turun. Ini berarti penanya menginginkan pernyataan dan penjelasan yang panjang dan mendalam.

Hal ini menandakan bahwa pertanyaan dengan penanda intonasi merupakan bentuk yang sering juga digunakan siswa untuk bertanya talam proses pembelajaran di kelas. Penanda intonasi Tanya ini memiliki dua kemungkinan jawaban, yaitu jawaban tertutup yaitu ya atau tidak, dan jawaban panjang dengan penjelasan yang lengkap.

c) Pertanyaan dengan menggunakan Partikel Tanya.

Penanda pertanyaan atau penanda untuk sebuah kalimat Tanya biasa disebut partikel, ada empat kata partikel penanda, adalah : lah, tah, kah, pun. Partikel-kah. Partikel ini bisa memperhalus suatu kalimat, tetapi bisa juga memberikan penegasan atau penekanan.

Dalam contoh kalimat berikut : Data (09) pernahkah kalian semua merasakan sakit hati? Kalimat pertanyaan ini memberikan penekanan pada kata pernah.

Data (10) benarkah minggu depan kita sudah libur? Pertanyaan dengan menggunakan partikel-kah, memberi penegasan pada kata yang menjadi tujuan pertanyaan. Tidak ada pernyataan panjang atau penjelasan untuk menjawab pertanyaan dengan menggunakan partikel-kah. Jika menggunakan partikel sebagai penanda pertanyaan, maka tidak perlu lagi menggunakan kata Tanya. Partikel kan. Partikel ini memberikan penekanan sebagai sebuah kalimat pertanyaan. Data (11) dia tidak bias membaca karena matanya rabun, benarkan?

Data (12) orang sehat selalu menjaga kebersihannyakan? Data (13) memberi pertolongan jangan mengharapkan imbalannyakan? Pertanyaan-pertanyaan yang menggunakan penanda partikel-kan, sebenarnya tidak memerlukan jawaban. Pertanyaanpertanyaan tersebut hanya merupakan sebuah penegasan saja.

Partikel lain, seperti ya, masa, dan oke, merupakan partikel-partikel penanda pertanyaan. Partikel tersebut merupakan penegasan yang tidak memerlukan jawaban panjang tetapi merupakan suatu pernyataan klarifikasi atau konfirmasi tentang sebuah pernyataan. Data (14) besok semua hadir lebih awal, benar ya? Data (15) tugas rumah siap semua ya? Data (16) kemarin kita sudah sepakat, oke? Data (17) Cuaca tidak mendukung untuk kita berolah raga, oke? Partikel penanda tersebut tidak menuntut jawaban penjelasan, tetapi hanya berfungsi sebagai pernyataan konfirmasi. 


\section{Fungsi Pertanyaan}

Pertanyaan-pertanyaan yang terjadi dalam kegiatan belajar-mengajar tidak dilakukan begitu saja tetapi mempunyai fungsi-fungsi tertentu, berkaitan dengan penanda yang digunakan.

1. Pertanyaan dengan penanda kata Tanya apa. Kata Tanya apa dipakai untuk menanyakan sesuatu benda atau keadaan atau perbuatan, dan segala sesuatu yang berkaitan dengan isi atau pokok bahasan. Jawaban dari pertanyaan yang menggunakan kata tanya "apa" adalah benda atau sesuatu, pengertian maupun penjelasan tentang hal yang ditanyakan.

2. Pertanyaan dengan menggunakan kata tanya atau penanda siapa. Siapa ini digunakan untuk mennanyakan orang. Jawaban dari pertanyaan yang menggunakan kata tanya "siapa" adalah orang atau pelaku serta pihak yang terlibat sesuatu hal yang ditanyakan.

3. Kata tanya "Kapan". Kata penanda pertanyaan ini berfungsi : untuk menanyakan waktu terjadinya sebuah atau suatu peristiwa atau kejadian. Jawaban dari pertanyaan yang menggunakan kata tanya "kapan" adalah waktu kejadian terjadinya sebuah peristiwa atau kejadian yang dapat berupa jam, hari, tanggal, bulan atau tahun.

4. Kata tanya "(Di, Ke, Dari) Mana". Penanda pertanyaan ini berfungsi : untuk menanyakan tempat berlangsungnya suatu peristiwa, lokasi yang akan dituju, tempat yang sedang ditgunakan atau yang telah didatangi. Jawaban dari pertanyaan yang menggunakan kata tanya "(di, ke, dari) mana" adalah tempat berlangsungnya suatu peristiwa/kejadian, lokasi yang akan dituju, tempat yang sedang dipakai atau yang telah didatangi.

5. Penanda pertanyaan dengan kata kata tanya "Mengapa" berfungsi untuk menanyakan sebab atau alasan suatu peristiwa terjadi. Jawaban dari pertanyaan yang menggunakan kata tanya "mengapa" adalah penjelasan tentang sebab atau alasan sebuah peristiwa yang terjadi, dan ditandai dengan pemakaian konjungsiatau kata hubung 'karena' atau 'sebab'.

6. Penanda pertanyaan dengan kata tanya "Bagaimana" Penanda tanya ini Berfungsi : untuk menanyakan suatu keadaan atau menanyakan kejelasan tentang sesuatu hal, cara atau proses pengerjaan sesuatu. Jawaban dari pertanyaan yang menggunakan penanda tanya "bagaimana" adalah penjelasan tentang suatu keadaan, cara atau proses terhadap sesuatu hal yang ditanyakan.

7. Penanda tanya "Berapa", merupakan penanda pertanyaan yang berfungsi untuk menanyakan, jumlah, banyaknya atau satuan. Secara umum fungsi dari pertanyaanpertanyaan yang dikemukakan siswa kepada guru maupun kepada sesame siswa dalam proses pembelajaran di kelas merupakan fungsi untuk klarifikasi, konfirmasi dan sebagai retorika. 


\section{Pertanyaan Berdasarkan Tingkat Kognisi}

Pertanyaan-pertanyaan siswa dalam proses pembelajaran di kelas dikategorikan menjadi 6 jenis menurut Bloom (dalam Rofiuddin dan Mansur, 1987). Pertanyaanpertanyaan tersebut yaitu : (1) Pertanyaan pengetahuan, (2) pertanyaan pemahaman, (3) pertanyaan aplikasi, (4) pertanyaan analisis, (5) pertanyaan sintesis dan (6) pertanyaan evaluasi. Keenam jenis pertanyaan kognisi ini disingkat atau dikenal dengan istilah, C1, untuk tingkat pengetahuan, C2 untuk tingkat pemahaman, C3 untuk tingkat aplikasi, C4 untuk tingkat analisis, C5 untuk tingkat sintesis, dan C6 untuk tingkat evaluasi.

Berdasarkan hasil analisis data penelitian ini, terungkap bahwa pertanyaanpertanyaan siswa berdasarkan tingkat berpikir kognisi siswa SMP kelas VIII dalam proses pembelajaran di kelas berdasarkan Taksonomi Bloom, kebanyakan berupa pertanyaanpertanyaan mengingat dan memahami. Hal ini berarti masih berada pada tingkatan berfikir tingkat rendah. Hal ini dipahami karena siswa SMP kelas VIII memang masih perlu banyak belajar dan berpikir. Kematangan berpikir belum tampak karena usia masih terlalu muda.

Berikut ini ditampilkan gamar tingkatan atau level ranah kognitif menurut Bloom Level ranah ini dapat digambarkan dalam bentuk piramida berikut:

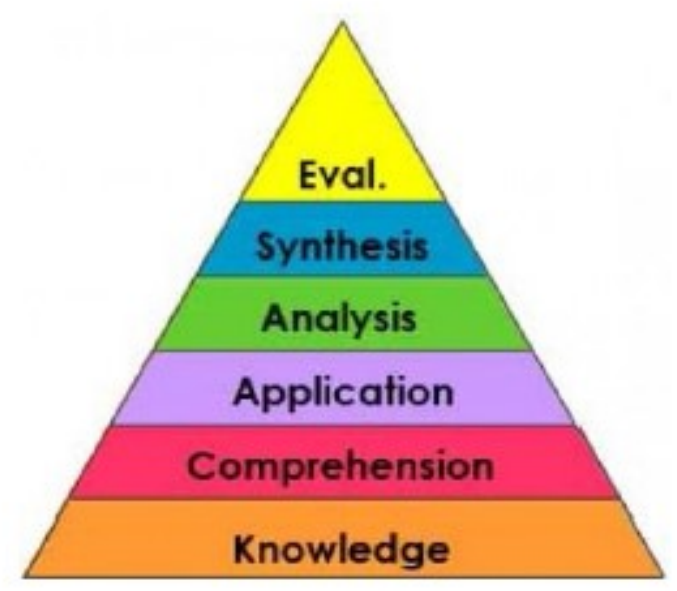

Tingkatan berfikir kognitif menurut taxonomi bloom

Piramida ini terlihat bahwa level terbawah yaitu knowledge, comprehension dan apllication (tiga level pertama ini, merupakan Lower Order Thinking Skills, sedangkan tiga level berikutnya Higher Order Thinking Skill. Namun demikian pembuatan level ini bukan berarti bahwa lower level tidak penting. Justru lower order thinking skill ini harus dilalui dulu untuk naik ke tingkat berikutnya. Skema ini hanya menunjukkan bahwa semakin tinggi semakin sulit kemampuan berpikir seseorang. 


\begin{tabular}{|c|c|c|c|}
\hline $\mathrm{NO}$ & KATAGORI & PENJELASAN & KATA KERJA KUNCI \\
\hline 1 & Pengetahuan & $\begin{array}{l}\text { Kemampuan menyebutkan atau } \\
\text { menjelaskan kembali } \\
\text { Contoh: menyatakan kebijakan. }\end{array}$ & $\begin{array}{l}\text { Mendefinisikan, menyusun daftar, } \\
\text { menamai, menyatakan, } \\
\text { mengidentifikasikan, mengetahui, } \\
\text { menyebutkan, membuat rerangka, } \\
\text { menggaris bawahi, menggambarkan, } \\
\text { menjodohkan, memilih }\end{array}$ \\
\hline 2 & Pemahaman & $\begin{array}{l}\text { Kemampuan memahami } \\
\text { instruksi/masalah, } \\
\text { menginterpretasikan dan } \\
\text { menyatakan kembali dengan } \\
\text { kata-kata sendiri } \\
\text { Contoh : Menuliskan kembali } \\
\text { atau merangkum materi } \\
\text { pelajaran }\end{array}$ & $\begin{array}{l}\text { Menerangkan, menjelaskan , menguraikan, } \\
\text { membedakan, menginterpretasikan, } \\
\text { merumuskan, memperkirakan, meramalkan, } \\
\text { menggeneralisir, menterjemahkan, } \\
\text { mengubah, } \\
\text { memberi contoh, memperluas, menyatakan } \\
\text { kembali, menganalogikan, merangkum }\end{array}$ \\
\hline 3 & Penerapan & $\begin{array}{l}\text { Kemampuan menggunakan } \\
\text { kons ep dalam praktek atau } \\
\text { situasiyang baru } \\
\text { Contoh: Menggunakan } \\
\text { pedoman/ aturan dalam } \\
\text { menghitung gaji pegawai. }\end{array}$ & $\begin{array}{l}\text { Menerapkan, mengubah, menghitung, } \\
\text { melengkapi, menemukan. membuktikan, } \\
\text { menggunakan, mendemon-strasikan, } \\
\text { memani- pulasi, memodifikasi, } \\
\text { menyesuaikan, menunjukkan, } \\
\text { mengoperasikan, menyiapkan, } \\
\text { menyediakan, menghasilkan. }\end{array}$ \\
\hline 4 & Analisa & \begin{tabular}{|l|} 
Kemampuan memisahkan \\
konsep kedalam beberapa \\
komponen untuk \\
memperolehpemahaman yang \\
lebih luas atas dampak \\
komponen - komponen \\
terhadap konsep tersebut secara \\
utuh. \\
Contoh: Menganalis penyebab \\
meningkatnya Harga pokok \\
penjualan dalam laporan \\
keuangan dengan memisahkan \\
komponen-komponennya. \\
\end{tabular} & $\begin{array}{l}\text { Menganalisa, mendiskriminasi kan, } \\
\text { membuat skema /diagram, membedakan, } \\
\text { membandingkan, mengkontraskan, } \\
\text { memisahkan, membagi, menghubungkan, } \\
\text { menunjukan hubungan antara variabel, } \\
\text { memilih, memecah menjadi beberapa } \\
\text { bagian, } \\
\text { menyisihkan, mempertentangkan. }\end{array}$ \\
\hline 5 & Sintesa & $\begin{array}{l}\text { Kemampuan merangkai atau } \\
\text { menyusun kembali } \\
\text { komponenkomponen } \\
\text { dalam rangka menciptakan arti } \\
\text { pemahaman / struktur baru. } \\
\text { Contoh: Menyusun kurikulum } \\
\text { dengan mengintegrasikan } \\
\text { pendapat dan materi dari } \\
\text { beberapa sumber }\end{array}$ & $\begin{array}{l}\text { Mengkategorikan mengkombinasi kan, } \\
\text { mengatur memodifikasi, mendisain, } \\
\text { mengintegrasikan, mengorganisir, } \\
\text { mengkompilasi, mengarang, menciptakan, } \\
\text { menyusun kembali, menulis kembali, } \\
\text { merancang, merangkai, merevisi, } \\
\text { menghubungkan, merekonstruksi, } \\
\text { menyimpulkan, mempolakan }\end{array}$ \\
\hline 6 & Evaluasi & $\begin{array}{l}\text { Kemampuan mengevaluasi dan } \\
\text { menilai sesuatu berdasarkan } \\
\text { norma, acuan atau kriteria. } \\
\text { Contoh: Membandingkan hasil } \\
\text { ujian siswa dengan kunci } \\
\text { jawaban. }\end{array}$ & $\begin{array}{l}\text { Mengkaji ulang, membandingkan, } \\
\text { menyimpulkan, mengkritik, } \\
\text { mengkontraskan, mempertentangkan } \\
\text { menjustifikasi, mempertahankan, } \\
\text { mengevaluasi, membuktikan, } \\
\text { memperhitungkan, menghasilkan, } \\
\text { menyesuaikan, mengkoreksi, melengkapi, } \\
\text { menemukan. }\end{array}$ \\
\hline
\end{tabular}


Pertanyaan Kognitif Siswa dalam Pembelajaran Bahasa Indonesia dengan Pendekatan Kontekstual di SMP Kartika Ambon

\section{KESIMPULAN}

Pertanyaan-pertanyaan kognitif siswa SMP yang terjadi dalam proses pembelajaran di kelas menunjukkan bahwa siswa-siswa tersebut menginginkan suatu suasana pembelajaran yang kondusif, interaksi yang terjadi membuat suasana pembelajaran tidak membosankan. Hasil penelitian membuktikan bahwa siswa dapat membuat pertanyaan dalam berbagai bentuk. Terungkap bahwa bentuk-bentuk pertanyaan yaitu dengan (1) menggunakan kata-kata Tanya, (2) menggunakan intonasi Tanya, dan (3) menggunakan partikel Tanya.

Fungsi dari pertanyaan-pertanyaan yang diajukan siswa dalam proses pembelajaran mempunyai berbagai fungsi sesuai dengan konteks percakapan atau konteks pembelajaran dengan materi yang berbeda-beda. Fungsi pertanyaan yaitu: untuk memperoleh penjelasan atau jawaban sebagai (1) klarifikasi, (2) konfirmasi, dan (3) retorika.

Pertanyaan berdasarkan tingkat kognisi siswa, ternyata bahwa siswa SMP Kelas VIII sebagian besar masih berupa pertanyaan berada pada tingkat rendah yaitu $\mathrm{C} 1$ dan $\mathrm{C} 2$ atau pada tingkat mengingat dan memahami, yaitu masih berada pada tingkat berpikir rendah.

\section{DAFTAR PUSTAKA}

Bogdan dan Bikklen 1982, Qualitative Research For Education: An Introduction to Theory and Methods. Allyn and Bacon, Inc: Boston London

Miles, M., \& Huberman. M. 1992. Qualitative Data Analysis: An Expanded Sourcebook. Beverly Hills: SAGE Publication Inc.

Nurhadi. 2002. Pendekatan Kontekstual. CTL. Jakarta: Depdiknas.

Suparno, 2003. Tingkat Kemahiran Berkomunikasi Lisan dalam Konteks Instruksional Guru

Sekolah Dasar Jawa Timur. Malang: Lembaga Penelitian UM. Malang.

Syafi' ie. 2001. Proses Belajar Mengajar. Surabaya: Airlangga Press. 
